\title{
Isolation and characterization of polymorphic microsatellite loci of the Chinese muntjac (Muntiacus reevesi)
}

\author{
H. Wang*, X. Luo*, W.B. Shi and B.W. Zhang \\ School of Life Science, Anhui University, Hefei, China \\ *These authors contributed equally to this study. \\ Corresponding author: B.W. Zhang \\ E-mail: zhangbw@ahu.edu.cn
}

Genet. Mol. Res. 13 (1): 1905-1908 (2014)

Received January 21, 2013

Accepted August 5, 2013

Published March 17, 2014

DOI http://dx.doi.org/10.4238/2014.March.17.18

\begin{abstract}
Eight polymorphic microsatellite markers for Muntiacus reevesi were identified and characterized in this study. The number of alleles per locus ranged from 3 to 10 across $24-48$ samples. The loci showed expected and observed heterozygosities of 0.577-0.876 and 0.387-0.933, respectively, with an average polymorphic information content value of 0.682 . These markers should be a useful tool for further population and conservation genetic studies of Muntiacus reevesi.
\end{abstract}

Key words: Chinese muntjac; Muntiacus reevesi; Microsatellite; Polymorphism; Population genetics 


\section{INTRODUCTION}

The Chinese muntjac (Muntiacus reevesi) is a small deer species with a native distribution centered in South China and parts of Southeast Asia (Zhang et al., 2004). It was introduced to England in the 19th century and has expanded its range broadly in the last 30 years (Harris et al., 1995). In some areas, M. reevesi density became so high that it was considered to be exerting a negative impact on timber production and on the biodiversity and conservation interests of forests (Putman and Moore, 1998; Fuller and Gill, 2001; Joys et al., 2004; Rooney et al., 2004). It has also been suggested that the roe deer (Capreolus capreolus) may suffer from competition with introduced muntjac populations (Chapman et al., 1993; Staines et al., 1998; Hemami et al., 2005). In China, however, the $M$. reevesi population has declined sharply due to habitat degradation and overhunting, and it is in urgent need of protection (Ye et al., 2008). Unfortunately, little attention has been paid to its conservation, apart from a few ecological and phylogeographical studies (Shi et al., 2010). In this investigation, we developed eight polymorphic microsatellite markers that can be used to study the population and conservation genetics of $M$. reevesi, and help to determine and identify effective conservation measures for this species.

\section{MATERIAL AND METHODS}

Microsatellite library enrichment was performed following the fast isolation by amplified-fragment length polymorphism (AFLP) of sequences containing repeats (FIASCO) protocol (Zane et al., 2002). Genomic DNA from the muscle tissue of one individual was extracted and purified using the EasyPure Genomic DNA kit (TransGen Biotech) following manufacturer guidelines. Then, it was digested by the MesI restriction enzyme (New England Biolabs) and ligated to a double-stranded MseI AFLP adaptor (MseI F: 5'-TACTCAGGACTCAT-3' and MseI R: 5'-GACGATGAGTCCTGAG-3') at $37^{\circ} \mathrm{C}$ for $3 \mathrm{~h}$. The digested and ligated product was then amplified using an MseI-N primer (5'-GATGAGTCCTGAGTAAN-3') for 26 cycles. After denaturation, DNA was hybridized with 5'-biotinylated (AC) $)_{12}$ oligonucleotide probes. Hybridization products were captured by Streptavidin MagneSphere Paramagnetic Particles (Promega) and unhybridized DNA was washed away. Enriched fragments were recovered from the denaturation steps by polymerase chain reaction (PCR) amplification with the MseI-N primer.

Agarose gel visualization of amplified fragments should appear in PCRs as a smear above 200 bp (Zane et al., 2002). PCR products were then ligated into the pEASY-T1 Simple Cloning Vector (TransGen Biotech) and transferred to Trans5 $\alpha$ Chemically Competent Cells (TransGen Biotech). Recombinants were screened by PCR using three primers: vector primers (M13F and $\mathrm{M} 13 \mathrm{R})$ and the $(\mathrm{AC})_{12}$ oligonucleotide. The lanes showing multiple bands on $2 \%$ agarose gel electrophoresis were considered putative microsatellite repeats. Plasmids from positive clones were sequenced and primers were designed by the Primer Premier 5 software (Lalitha, 2000).

PCRs were performed in 20- $\mu \mathrm{L}$ volumes containing 100-200 ng genomic DNA, 10 $\mu \mathrm{L} 2 \mathrm{X}$ EasyTaq PCR Supermix (TransGen Biotech), and 2.5 pmol of each primer pair (the forward primer was fluorescently labeled with FAM, HEX, or TAMRA). Amplification was performed on an Applied Biosystems (ABI) 2720 Thermal Cycler under the following conditions: initial denaturation at $95^{\circ} \mathrm{C}$ for $5 \mathrm{~min}$; followed by 32 cycles of $30 \mathrm{~s}$ at $94^{\circ} \mathrm{C}, 30 \mathrm{~s}$ at the annealing temperature (Table 1), $40 \mathrm{~s}$ at $72^{\circ} \mathrm{C}$; and a final extension at $72^{\circ} \mathrm{C}$ for $10 \mathrm{~min}$. All 
PCR products were separated on an ABI PRISM 3730 genetic analyzer (Applied Biosystems) with a GS500 size standard, and analyzed using GENEMARKER (version 1.3, SoftGenetics LLC). Allele size ranges, numbers of alleles, observed heterozygosity, expected heterozygosity, and polymorphic information content values were calculated using GENETIX version 4.0 (Belkhir et al., 2001). Deviations from Hardy-Weinberg equilibrium and linkage disequilibrium at each locus were measured using GENEPOP version 4.0 (Rousset, 2008).

\begin{tabular}{|c|c|c|c|c|c|c|c|c|c|}
\hline Locus & Primer sequences $\left(5^{\prime}-3^{\prime}\right)$ & $\begin{array}{l}\text { Repeat } \\
\text { motif }\end{array}$ & $\begin{array}{l}\mathrm{Ta} \\
\left({ }^{\circ} \mathrm{C}\right)\end{array}$ & $\begin{array}{l}\text { Size range } \\
\text { (bp) }\end{array}$ & $\begin{array}{l}\text { No. of } \\
\text { alleles }\end{array}$ & $H_{\mathrm{o}}$ & $H_{\mathrm{E}}$ & PIC & Accession No. \\
\hline Mre35 & $\begin{array}{l}\text { F: GTCCTGGTAAATGGGGTTCA } \\
\text { R: GCCGATGCTTTGTTCTCC }\end{array}$ & $(\mathrm{GT})_{31}$ & 57 & $194-202$ & 3 & 0.533 & 0.577 & 0.496 & KC166223 \\
\hline Mre39 & $\begin{array}{l}\text { F: AATTGGGAGACTGGGACTGAGA } \\
\text { R: TGAATGAATGAAGCTGCTTGTAA }\end{array}$ & $(\mathrm{AC})_{17}$ & 57 & $237-255$ & 6 & 0.714 & 0.820 & 0.761 & KC166224 \\
\hline Mre49 & $\begin{array}{l}\text { F: CGGCCAATTATCTGCGAGTGTC } \\
\text { R: CTAGGCAGTGCTTGGTTGAGAA }\end{array}$ & $(\mathrm{AC})_{30}$ & 57 & $276-282$ & 4 & 0.625 & 0.597 & 0.510 & KC166225 \\
\hline Mre61 & $\begin{array}{l}\text { F: AAGGGGGACGTTGGTTTGAC } \\
\text { R: GATGCCTGTGTGGACAGAGTTTGA }\end{array}$ & $(\mathrm{AC})_{18}$ & 57 & $187-211$ & 9 & 0.933 & 0.876 & 0.83 & KC166226 \\
\hline Mre04* & $\begin{array}{l}\text { F: GTCACAAGCCGGCATTCAGAG } \\
\text { R: ATGCCCTTTGTTCCTTCCTTATTG }\end{array}$ & $(\mathrm{AC})_{20}$ & 57 & $329-339$ & 6 & 0.387 & $0.644^{*}$ & 0.568 & KC166227 \\
\hline Mre22 & $\begin{array}{l}\text { F: CAAACATGACTGAGCGACTGA } \\
\text { R: TGCATCTCTTTCTAACTCCACATT }\end{array}$ & $(\mathrm{AC})_{16}$ & 57 & $132-144$ & 6 & 0.625 & 0.717 & 0.658 & KC166228 \\
\hline Mre383 & $\begin{array}{l}\text { F: AGACGGTCACCACTTCTATTAC } \\
\text { R: AGTAGAGTTTGTGTGTGTGAGG }\end{array}$ & $(\mathrm{AC})_{21}$ & 57 & $172-190$ & 9 & 0.857 & 0.838 & 0.808 & KC166229 \\
\hline Mre448* & $\begin{array}{l}\text { F: GAGACAGCAGGATGAGATGT } \\
\text { R: ACAGTAGCCTCTCCTTCCTC }\end{array}$ & $(\mathrm{TG})_{12}$ & 57 & 188-214 & 10 & 0.438 & $0.855^{*}$ & 0.453 & КC166230 \\
\hline
\end{tabular}

*Indicates significant deviations from Hardy-Weinberg equilibrium. Ta $=$ annealing temperature; $H_{\mathrm{O}}=$ observed heterozygosity; $H_{\mathrm{E}}=$ expected heterozygosity; $\mathrm{PIC}=$ polymorphic information content value.

\section{RESULTS AND DISCUSSION}

Plasmids from 70 positive clones were sequenced and 20 primers were designed. Among the 20 primer pairs, 12 microsatellite loci produced consistent amplifications and were chosen for further analysis by screening 24-48 individuals. The analysis results showed that the number of alleles ranged from 3 to 10 ; the expected heterozygosity ranged from 0.577 to 0.876 and observed heterozygosy ranged from 0.387 to 0.933 (Table 1 ). The average polymorphic information content value was 0.682 . Together, these results indicated that these loci were polymorphic. No deviation from Hardy-Weinberg equilibrium was observed, except for loci Mre04 and Mre448. We did not detect any linkage disequilibrium between these loci.

These polymorphic microsatellite loci may be useful for investigating population structure, levels of gene flow, mating systems, and conservation genetics of M. reevesi.

\section{ACKNOWLEDGMENTS}

Research supported by the Key Science and Technology Financing Projects of the Ministry of Education (2012), the Foundation for Young and Key Teachers, and the Talent Cultivation Project of Anhui University (\#02203104/04). We also acknowledge Longhui Lin, Luqian Mao, Guanju Yu, Rong Fan, Yinxu Hou, and Jian Chen for their help in sampling and laboratory work. 


\section{REFERENCES}

Belkhir K, Borsa P and Chikhi L (2001). 1996-2001 GENETIX 4.02, Logiciel Sous Windows ${ }^{\mathrm{TM}}$ Pour la Génétique des Populations. Université de Montpellier II, Montpellier.

Chapman NG, Claydon K, Claydon M, Forde PG, et al. (1993). Sympatric populations of muntjac (Muntiacus reevesi) and roe deer (Capreolus capreolus): a comparative analysis of their ranging behaviour social organization and activity. J. Zool. Lond. 229: 623-640.

Fuller RJ and Gill RMA (2001). Ecological impacts of deer in woodland. Forestry 74: 189-192.

Harris S, Morris P, Wray S and Yalden D (1995). A Review of British Mammals: Population Estimates and Conservation Status of British Mammals Other than Cetaceans. JNCC, Peterborough.

Hemami M, Watkinson AR and Dolman PM (2005). Population densities and habitat associations of introduced muntjac Muntiacus reevesi and native roe deer Capreolus capreolus in a lowland pine forest. For. Ecol. Manag. 215: 224-238.

Joys AC, Fuller RJ and Dolman PM (2004). Influences of deer browsing, coppice history and standard trees on the growth and development of vegetation structure in coppiced woods in low-land England. For. Ecol. Manag. 202: 23-37.

Lalitha S (2000). Primer premier 5. Biotechnol. Software Internet Rep. 1: 270-272.

Putman RJ and Moore NP (1998). Impact of deer in lowland Britain on agriculture, forestry and conservation habitats. Mamm. Rev. 28: 141-164.

Rooney TP, Wiegmann SM, Rogers DA and Waller DM (2004). Biotic impoverishment and homogenization in unfragmented forest understory communities. Conserv. Biol. 18: 787-798.

Rousset F (2008). Genepop'007: a complete re-implementation of the genepop software for Windows and Linux. Mol. Ecol. Resour. 8: 103-106.

Shi WB, Wang H, Zhu LF, Zhu QQ, et al. (2010). The genetic divergence and gene flow pattern of two muntjac deer (Muntiacus reevesi) populations, Wannan and Dabie mountains, from the effect of Yangtze river and the late Pleistocene glacial oscillations. Acta. Theriol. Sin. 30: 390-399.

Staines B, Palmer SCF, Wyllie I, Gill R, et al. (1998). Desk and Limited Field Studies to Analyze the Major Factor in Fluencing Regional Deer Populations and Ranging Behavior. Institute of Terrestrial Ecology, Banchory.

Ye WW, Zhu T, Hu CC, Zhang CL, et al. (2008). A molecular genetic approach for species identification of several forensic animal samples. Acta Theriol. Sin. 28: 434-439.

Zane L, Bargelloni L and Patarnello T (2002). Strategies for microsatellite isolation: a review. Mol. Ecol. 11: 1-16.

Zhang XM, Shan XN, Shi YF, Zhang HJ, et al. (2004). Sequence and organization of Muntiacus reevesi mitochondrial genome. Yi. Chuan 26: 849-853. 